\title{
PW02-041 - Canakinumab treatment regimens in CAPS-patients
}

\author{
F Hofer ${ }^{1}$, T Endres ${ }^{1}$, B Kortus-Götze ${ }^{2}$, N Blank ${ }^{3}$, E Weißbarth-Riedel ${ }^{4}$, C Schuetz ${ }^{5}$, T Kallinich ${ }^{6}$, K Krause ${ }^{7}$, C Rietschel $^{8}$, \\ G Horneff ${ }^{9}$, J Kuemmerle-Deschner ${ }^{1 *}$
}

From 7th Congress of International Society of Systemic Auto-Inflammatory Diseases (ISSAID) Lausanne, Switerland. 22-26 May 2013

\section{Introduction}

Canakinumab is a recombinant monoclonal fully human antibody against Interleukin- $1 \beta$ and currently the only drug approved for the treatment of CAPS in Europe. Current dose recommendations are 150mg (body weight $>40 \mathrm{~kg}$ ) respectively $2 \mathrm{mg} / \mathrm{kg}$ bodyweight ( 15 to $40 \mathrm{~kg}$ ) every 8 weeks but yield insufficient response in some individuals, especially in children and patients with severe phenotypes [1].

\section{Objectives}

In this study we analyzed the response to daily practice (in contrast to trial condition) canakinumab treatment regimens in CAPS-patients with focus on age, mutation and clinical presentation and the necessity and effect of dose adjustment.

\section{Methods}

An observational national multicenter study was conducted. CAPS-Patients were included if they received at least two doses of canakinumab. Data included information regarding demographics, treatment, clinical disease activity and inflammatory markers (including SAA, CRP, S100, ESR, IL-6). Response to treatment was assessed using CAPS-disease activity scores, CRP and/or SAA levels.

\section{Results}

A cohort of 68 patients with CAPS was analyzed. At the beginning of treatment 27 patients had been younger than 18 years with a median age of 25.4 years (range 22 months to 73 years). The most frequent mutations were R260W, A439V, E311K, V198M, Q703K and most

'Department of Pediatrics, Division of Pediatric Rheumatology, University

Hospital Tuebingen, Tuebingen, Germany

Full list of author information is available at the end of the article patients showed MWS or FCAS/MWS phenotype (3 patients with NOMID, 4 with MWS/NOMID). The median treatment duration was 855 days (range: 28-1973 days). In 57\% (39) of patients full response was sustained until next scheduled drug application (34\% (23) partial remission). With standard treatment $31 \%$ (21) of patients achieved full response. In $44 \%$ (30) of all patients canakinumab dose and/or application interval was increased above the standard regimen (2/3 NOMID, 3/4 MWS/NOMID). Two serious adverse events were reported (severe infection, osteonecrosis), mild and moderate adverse events were mostly upper respiratory tract infections but almost no injection site reactions.

\section{Conclusion}

Most CAPS-Patients achieve full remission with canakinumab. However, almost $50 \%$ of patients, particularly children, require dose adjustment. Dose increase was well tolerated and full remission was achieved without an increased rate of adverse events.

\section{Competing interests}

F. Hofer: None declared, T. Endres: None declared, B. Kortus-Götze: None declared, N. Blank: None declared, E. Weißbarth-Riedel: None declared, C. Schuetz: None declared, T. Kallinich: None declared, K. Krause: None declared, C. Rietschel : None declared, G. Horneff: None declared, J. Kuemmerle-Deschner Grant / Research Support from: NOVARTIS, Consultant for: NOVARTIS

\section{Authors' details}

'Department of Pediatrics, Division of Pediatric Rheumatology, University Hospital Tuebingen, Tuebingen, Germany. ${ }^{2}$ Klinik für Innere Medizin, Schwerpunkt Nephrologie, Universitätsklinikum Marburg, Marburg, Germany. ${ }^{3}$ Hämatologie, Onkologie u. Rheumatologie, Universitätsklinikum Heidelberg, Heidelberg, Germany. ${ }^{4}$ Kinderrheumatologische Ambulanz,

Universitätsklinikum Eppendorf, Hamburg, Germany. ${ }^{5}$ Klinik für Kinder und Jugendmedizin, Universitätsklinikum Ulm, Ulm, Germany. ${ }^{6}$ Kinderklinik 
Sektion Rheumatologie, Charité Campus Virchow, Germany. " $A$ AllergieCentrum Charité", Klinik für Dermatologie, Charité Campus Mitte, Berlin, Germany. ${ }^{8}$ Rheumatologische Ambulanz, Clementine Kinderhospital, Frankfurt, Germany. ${ }^{9}$ Abteilung für. Allgemeine Kinder- und Jugendmedizin, Asklepios Klinik Sankt Augustin, St. Augustin, Germany.

Published: 8 November 2013

\section{Reference}

1. Kuemmerle-Deschner JB: Efficacy of antibiotic therapy for SAPHO syndrome is lost after its discontinuation: an interventional study. Ann Rheum Dis 2011, 70:2095-2102.

doi:10.1186/1546-0096-11-S1-A182

Cite this article as: Hofer et al:: PW02-041 - Canakinumab treatment

regimens in CAPS-patients. Pediatric Rheumatology 2013 11(Suppl 1):A182.

\section{Submit your next manuscript to BioMed Central} and take full advantage of:

- Convenient online submission

- Thorough peer review

- No space constraints or color figure charges

- Immediate publication on acceptance

- Inclusion in PubMed, CAS, Scopus and Google Scholar

- Research which is freely available for redistribution

Submit your manuscript at www.biomedcentral.com/submit 